\title{
Cecília Meireles e a Mitologia Greco-Latina
}

\section{Cecília Meireles and the Greek- Latin Mythology}

\author{
Antony Cardoso Bezerra ${ }^{1}$ \\ https://orcid.org/0000-0002-2311-1390
}

\begin{abstract}
Resumo: A continuidade dos elementos da tradição clássica ao longo das épocas sucedâneas é marcante. No seio da Modernidade, em que a visita ao plano greco-latino é dominada por uma perspectivação histórica, não são raras as atribuições de novas qualidades a mitos e a lendas, num diálogo frutuoso. No contexto da poesia brasileira, uma autora realizou essa interface superiormente: Cecília Meireles. Em algumas composições de Vaga Música (1942) e de Mar Absoluto: e outros poemas (1945), a poetisa elabora fábulas da Mitologia Greco-Latina em nova clave, mantendo e renovando suas características primevas. Após a discussão do papel exercido pelo influxo da Antiguidade na Modernidade e a breve exposição dos termos em que Cecília Meireles dialoga com a tradição, analisa-se um corpus de quatro poemas que refiguram três personagens do mundo clássico: Caronte, Diana e Narciso. Em cada comentário aos poemas, oferece-se um bosquejo literário e históricocrítico dos mitos, para, posteriormente, analisarem-se os procedimentos linguísticos e poéticos empregados pela escritora para a elaboração dos textos.
\end{abstract}

Palavras-chave: Cecília Meireles; Mitologia Greco-Latina; Diálogo.

Abstract: The remains of the classical tradition in the posterity is remarkable. In the Modern Era, in which the visitations to the Greek-Latin world are permeated with a historical perspective, the conference of new characteristics to myths and legends is not rare, in a fruitful dialogue. In the sphere of Brazilian poetry, there is an author who promoted this exchange in a superior way - Cecília Meireles. In some compositions of the books Vaga Música (1942) and Mar Absoluto: e outros poemas (1945), the poetess elaborates fables of Greek-Latin Mythology in a new bias, by, at the same time, maintaining and renewing their original traits. After a discussion on the role played by the Classical Antiquity in the Modernity and a brief exposition on how Cecília Meireles converses with tradition, a corpus of four poems - on Charon, Diana and Narcissus, characters of the GreekLatin world - is analysed. Each one of the comments on the poems is associated to a literary, historical and critical presentation of the myths; afterwards, linguistic and poetical procedures employed by the writer to produce the pieces are scrutinised.

Keywords: Cecília Meireles; Greek-Latin Mythology; Dialogue.

\footnotetext{
${ }_{1}$ Professor Associado 1 da Licenciatura em Letras da Universidade Federal Rural de Pernambuco. E-mail: <a.cnc.1901@gmail.com>.
} 


\section{O Mundo Clássico e a Sua Recuperação}

Independentemente da esfera cultural que se tenha em mente, a Antiguidade Greco-Latina é inescapável. Fora a obviedade de nela se pensar quando se tiver em mente a Filosofia, a Arquitetura, a Arte, o Direito, a estratégia bélica ou os modos de governo, o mundo clássico lega modos de ser no mundo que, não por acaso, são sistematicamente recuperados em horizontes históricos posteriores. O projeto clássico está em diálogo com a escolástica, com a estética humanista, faz-se reviver na Renascença e no Neoclássico e, mesmo nos quadrantes que, em superfície, parecem o rechaçar, revela-se presente; caso, este, para se fica num exemplo, do Romantismo.

Tal condição se pode ilustrar, precisamente, com recurso ao poeta romântico inglês John Keats, que, em seu notório «Ode a uma Urna Grega», imprime uma marca que caracterizará a representação da Antiguidade no plano moderno: a da perspectivação temporal. Não que o Classicismo não o fizesse - o que dizer de Camões a sua refiguração do modelo vergiliano em Os Lusíadas? Mas é que, no Romantismo (no plano moderno, por extensão), o diálogo entre tempos se faz não apenas manifestamente, como, também, assume o papel de chave para o texto literário: é por, a partir do presente, olhar para uma imagem do passado que atravessa os tempos, que o eu poético manifesta o entendimento de que é, ele mesmo, um ser histórico. Não é demasiado lembrar a terceira estrofe do poema, que bem dimensiona o quadro delineado:

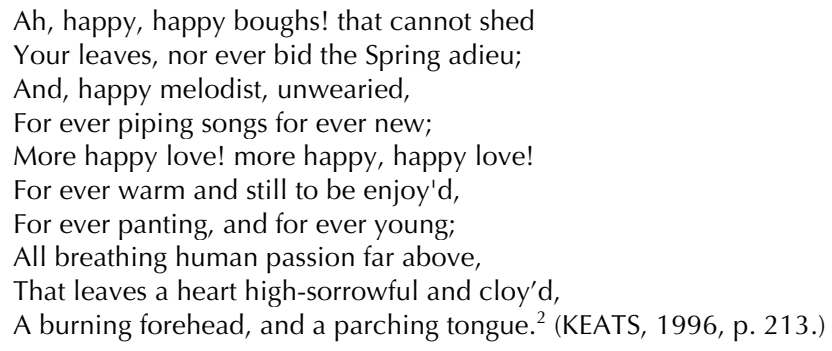

\footnotetext{
${ }^{2}$ Felizes, ramos felizes, que não podeis soltar

Vossas folhas, nem jamais dar adeus à primavera;

E tu, afortunado melodista, infatigável,

Para sempre tocando árias sempre novas;

Mais venturoso amor! Feliz, feliz amor!

Para sempre ardente, sem nunca ser possuído,

Sempre ofegante e para sempre jovem;

Muito, muito acima das paixões humanas,
} 
Em vez de se arvorar um pastor árcade, o enunciador caracteriza aquilo que vê na urna grega - vestígio material do passado que chega ao século 19 - e admira tudo aquilo que a peça representa. Fá-lo, portanto, a partir de seu presente: é o homem moderno que dialoga com uma relíquia, exaltando-lhe a permanência e os ideais que representa. ${ }^{3} \mathrm{~A}$ isso se pode dar o nome de perspectiva, ou, conforme o chamou o filólogo alemão Erich Auerbach, em ensaio que contempla o filósofo napolitano Giambattista Vico, de «historicismo». A partir da «convicção de que cada civilização e cada período tem suas próprias possibilidades de perfeição estética», as manifestações artísticas «devem ser compreendidas como produtos de condições peculiares variáveis, e julgadas de acordo com seu próprio desenvolvimento [...].» (AUERBACH, 2007, p. 341.) É a tríade, sustentada pelo estudioso germânico, que corresponde a época, lugar e individualidade. Por guardar essa visão, o pensamento de Auerbach converge para o olhar materializado em Keats, na medida em que «nada é mais contrário ao historicismo estético que a imitação de modelos», prática que derivaria em nortes modelares e absolutos (AUERBACH, 2007, p. 342). Desse eixo, o autor inglês, conforme exemplo acima, afasta-se não apenas em conteúdo, mas, ainda mais, em projeto estético. Não se trata de condição casual: conforme, mais uma vez, ensina Auerbach (2007, p. 343) é, particularmente, nas correntes pré-românticas e românticas que o historicismo ascende, espalhando-se por toda a Europa.

A percepção de se fazer parte de uma inscrição espaciotemporal não apaga o mundo clássico; em efetivo, anima-o, pois se parte do entendimento de que persiste justamente por ser renovado. Tal condição faz com que o clássico seja percebido com mais clareza e amplitude; tanto em seu legado, quanto nas formas que toma. A cautela, portanto, é necessária quando, a partir de um presente moderno, recupera-se um passado em vários quadrantes como modelar. Vale, a esse propósito, ter-se em mente a advertência feita por João Batista Toledo Prado:

\begin{abstract}
De fato, tornou-se já um lugar-comum fazer referência a todos os bens de cultura que a modernidade herdou do seu passado helênico-romano, e é mesmo quase impossível pensar nas modernas sociedades do Ocidente sem tributar à Antiguidade Clássica Greco-Latina seu quinhão de influência, termo com que geralmente se designam os variados graus de permanência dos bens civilizatórios gestados por gregos e romanos antigos
\end{abstract}

Que deixam o coração triste e entediado,

A fonte em brasa, a língua ressequida. (Trad. de Oswaldino Marques.) (KEATS, [19__], p. 43.)

${ }^{3}$ Embora se constitua como excurso, é curioso notar que o próprio entendimento que John Keats possuía do mundo grego fosse enevoado e tangencial: «[...] tinha visitado Roma, mas nunca se aventurara à travessia até à Grécia. Também não havia lido muita literatura antiga ou, pelo menos, não de maneira muito erudita. Praticamente não sabia coisa alguma de grego antigo, baseando-se inteiramente em traduções e no que via em museus.» (BEARD \& HENDERSON, 1998, p. 30.) Não deixa, essa condição, de consistir em ratificação do quanto o encantamento pelo mundo clássico se promove em variados níveis e processos. 
e que pervagaram tempo e espaço - mesmo quando reelaborados e transformados - replicando-se inúmeras vezes e em lugares sem conta. A própria ideia de um único bloco de culturas díspares, nascidas, mantidas de um fundo identitário comum, a que se chama Ocidente, tem, no mundo clássico, as suas raízes e razão de ser. (PRADO, 2011, p. 53-54.)

Independentemente da autoconsciência em relação ao que o passado deixa como herança e a sua efetiva reformulação formal ou conteudística, o fato é que a permanência clássica se afirma com as marcas que o tempo e as culturas Ihe emprestam. Prado ainda chamará a atenção à noção de «diálogo» quanto à relação estabelecida entre os horizontes históricos, pois não apenas o que antecede deixa um legado ao período que sucede, como também este revisita o passado e atribui-Ihe novas qualidades e perspectivações (PRADO, 2011, p. 54). Mais que ouvir o passado, o presente o reformula - e, no caso da poesia moderna, para se ficar numa manifestação humana dentre várias possíveis, revela novos sentidos e novas feições. Muito por isso, Mary Beard \& John Henderson afirmam:

\footnotetext{
[...] os clássicos fazem mais do que transbordar o reservatório imaginativo de nossa herança cultural. Oferecem uma série de precedentes para o comportamento pessoal, suficientemente diferentes dos da nossa própria experiência para desafiar nosso entendimento, mas semelhantes o bastante para nos irritar e abalar nossas certezas. (BEARD \& HENDERSON, 1998, p. 126.)
}

O diálogo — ou, em sentido mais sofisticado, uma dialética — permite não apenas revelar qual «clássico» atravessa as épocas, não apenas a recepção que um momento histórico faz do clássico, mas, ainda mais, o que as individualidades criadoras selecionam do manancial que se avoluma com o tempo, para, ao mesmo tempo em que recupera o passado, oferecerem uma imagem do próprio presente. É, precisamente, o que se faz por meio do texto poético. É, precisamente, o que realiza Cecília Meireles, poetisa moderna que entende não apenas o seu próprio quadrante, quanto, ainda mais, dialoga conscientemente com o passado, remodelandoo.

\section{Cecília Meireles: nótula sobre seu diálogo com a tradição}

Cecília Meireles (n. 1901; f. 1964), poetisa, contista, ensaísta e cronista brasileira, tem sua produção literária concentrada na primeira metade do século 20. Não raro reputada como herdeira da estética simbolista (cf. RAMOS, 1967, p. 153), está também no universo antigo um acervo que, se não é dominante, faz parte de sua poesia. Exemplo de tal se pode ter em seu 
segundo e em seu terceiro livros «modernos» ou «neossimbolistas»: Vaga Música (1942) e Mar Absoluto: e outros poemas (1945). ${ }^{4}$ Em algum sentido, esse bosquejo sinaliza condição para que o crítico Eduardo Peñuela Cañizal alertara: o fato de existir uma tendência, por parte do que ele chama de «a crítica», a encarar a obra da autora, «de modo geral, como algo uniforme». (PEÑUELA CAÑIZAL, 1966, p. 58.) É uma situação que se materializaria tanto no plano estilístico, quanto no temático.

\begin{abstract}
A relação de distância entre a escritora e as circunstâncias naturais não é sempre a mesma: há em toda sua obra duas coordenadas predominantes, de cujo uso depende a organização do mundo material em função do poético. Estas duas linhas mestras são as bases essenciais do reportamento indispensáveis a uma razoável compreensão do complexo imaginário. A alternância, na sua aplicação, motiva, na poesia, diferenças no que se refere à cosmovisão alentadora dos entes imaginários. (PEÑUELA CAÑIZAL, 1966, p. 58.)
\end{abstract}

O jogo de ausência e de presença caracterizado pelo analista — que se cria, assim, por meio de uma tensão filtrada pelo imaginário - acaba por assinalar um procedimento-chave por meio do qual a poetisa moderna se insere na tradição, que é o aproveitamento proteico do que a antecede. Muito óbvia, aqui, parece ser a associação de tal postura ao que o poeta e crítico anglo-saxão Thomas Stearns Eliot observou em seu notório ensaio «Tradição e Talento Individual», quando reflete sobre a condição do poeta na Modernidade:

Nenhum poeta, nenhum artista, tem sua significação completa sozinho. Seu significado e a apreciação que dele fazemos constituem a apreciação de sua relação com os poetas e os artistas mortos. Não se pode estimá-lo em si; é preciso situá-lo, para contraste e comparação, entre os mortos. (ELIOT, 1989, p. 39.)

Concretamente e tendo-se em mente o problema que ora se pretende enfrentar, a recuperação que Cecília Meireles faça de elementos da Antiguidade Clássica - em específico, da Mitologia Greco-Latina - corresponde tanto a um apoio em textos literários que estão sedimentados na cultura ocidental, quanto, ainda mais, num ponto de partida para que a intervenção da poetisa não apenas emule imagens consagradas das personagens retratadas, mas que ofereça-lhes novas feições, que não anulam as primordiais; antes, enriquecem-nas. Se se tratar, esse, de um índice de qualidade da produção poética de Cecília Meireles — e Eliot, de

\footnotetext{
${ }^{4}$ Em volume, Cecília Meireles estreou-se com o livro de sonetos Espectros (1919). Nele, há marcas do Parnasianismo. Nunca Mais... e Poema dos Poemas (1923) e Baladas para El-Rei (1925), por seu turno, guardam marcas profundas do Simbolismo. Nenhum dos três volumes foi incluído na Obra Poética, cuja 1.a ed., pela Aguilar, é de 1958. O livro que abre a coleção é Viagem (1939). Para a presente investigação, emprega-se a 3.a ed da Obra Poética, publicada pela Nova Aguilar (MEIRELES, 1985).
} 
certeza, assim pensaria - aí está ele. Seu deslinde se converte não apenas no ato de se flagrarem fatores análogos, mas, mais que isso, num artifício crítico que ao mesmo tempo (1) joga luz sobre a estruturação do texto poético conforme a autora a concebe; (2) explora as imagens da Mitologia Antiga em sua renovada configuração. Exegeta privilegiado da obra da poetisa, Darcy Damasceno observou, acerca do primeiro livro moderno de Cecília Meireles:

\footnotetext{
Viagem estava não só dentro de linhas tradicionais, como também aspirava a ser - e o foi - a primeira obra acima de fronteiras que haja aparecido no modernismo. Cumpria-se nela a preceptiva dos espiritualistas [grupo a que esteve vinculada a escritora], quando reclamavam para a renovação de nossas letras encadeamento com a tradição, sustentáculo filosófico e intenção de universalidade. (DAMASCENO, 1985, p. 18.)
}

O que anima essa nova etapa na lírica da autora é aquilo que se mostrará presente nas obras imediatamente sucedâneas (de que se extrai o corpus adiante analisado): uma capacidade de atualização residente não na pretensa desconstrução de um passado comum ao Ocidente; antes, o incremento por meio de um novo olhar, um olhar moderno, historicamente tangenciado e enriquecedor na medida em que apresenta novas alternativas a um plano sedimentado, que é o mítico. Mais uma vez, Damasceno parece pintar com precisão o quadro da poesia de Cecília Meireles à altura:

\footnotetext{
Sobre o mundo se estendem seus olhos, que tudo aceitam no espetáculo do real, o espírito, entretanto, está em permanente vigília, indagando, concluindo, atento à sabedoria de que no conceito geral cada coisa existe porque independe de si e tudo se subordina à mecânica do universo. (DAMASCENO, 1985, p. 18.)

[A Propósito do poema «Terra», do livro Viagem.] Os dados da realidade apreendida foram filtrados, sensibilizados e feitos fabulação lírica [...]. (DAMASCENO, 1985, p. 19.)
}

Conforme salientou Peñuela Cañizal (1966, p. 67) — também em diálogo com Damasceno —: ao pensar nos elementos do mundo natural, Cecília Meireles os funde a sentimentos, num processo de correspondência que, partindo de uma realidade reconhecível no ato da leitura (simples, portanto), recebe novas marcas pelo recurso ao imaginário do eu poético, que, assim, abre as portas dos símbolos e da polissemia. Em algum sentido, o enunciador que testa os limites da realidade, em exercícios de expressão, refigura-a vividamente. Muito nesse sentido, leem-se criticamente os poemas em que Cecília Meireles se apropria de uma realidade mítica e literária.

\section{Três Personagens da Mitologia Clássica sob o Olhar de Cecília Meireles: Caronte, Diana e Narciso}


Dentro do legado da Antiguidade Clássica ao Ocidente, a mitologia apresenta posição de vulto, pela função etiológica que o mito exerce em todo corpo social. O teórico alemão André Jolles, sobre tal plano, enxerga a passagem do mythos ao logos, dado que o homem grego, pelo grau de desenvolvimento de sua civilização, era capaz de compreender os fenômenos da natureza (cf. JOLLES, 1976, p. 94). Ou seja, diferentemente do homem primitivo, em que vigorava apenas a explicação mítica, no mundo helênico (bem como no latino), esta convivia com aquela haurida empiricamente. Mas não é apenas nessa dimensão que o mito revela sua importância para a compreensão do mundo antigo: também por seu emprego no que, hoje, pode-se entender como Literatura, o mito tem muito a dizer sobre os usos da linguagem na Antiguidade. Na poesia lírica, na épica e no drama trágico, a presença dos deuses greco-latinos é decisiva e traduz não apenas aspectos da vida no mundo antigo, mas, indo além, ideais capazes de jogar luz sobre a compreensão que o homem desse quadrante possuía da existência em sentido lato. Quando recuperado, longe de desfazer o olhar de setores da História subsequentes, o manancial da Mitologia Clássica com eles estabeleceu proveitoso diálogo, conforme esclarece Junito de Souza Brandão, refutando a noção de que retomar-se o mundo clássico consistiria numa derivação mofina da tradição judaico-cristã ${ }^{5}$ :

\begin{abstract}
Trata-se de compreender a razão pela qual a Cultura Ocidental se voltou tão intensamente para a Grécia durante o Renascimento, o que muitos têm compreendido como um retrocesso ao paganismo e um consequente desvirtuamento do Cristianismo. No entanto, lado a lado com a intolerância da Inquisição e sua obra repressiva das variáveis míticas (heresias), percebemos, no Renascimento, a Consciência da fé cristã, não só com símbolos da religião greco-romana e egípcia, como em toda a sorte de crenças, superstições e magia. Foi nesta convivência entre religião, alquimia, astrologia e superstição que nasceu o humanismo europeu, útero e berço da ciência moderna. Não vejo nisso um retrocesso do Cristianismo e sim um avanço. A árvore mítica judaico-cristã foi buscar em outras culturas o material imaginário necessário para implantar a transição cultural do Self Cultural e encontrou, na Mitologia Grega, uma fonte inesgotável de símbolos de convivência com as forças da natureza. (BRANDÃO, 2000, p. 11.)
\end{abstract}

É o diálogo entre planos, mais uma vez profícuo, que ao mesmo tempo enriquece a tradição cultural e mística do Ocidente, mas que também renova a compreensão do elemento mítico conforme figurado no passado histórico. Em que pese às limitações impostas por um referencial de raiz psicologizante, Brandão consegue sinalizar um dimensionamento histórico do mito -

${ }^{5}$ Não é demais lembrar, é decisiva a vinculação de Cecília Meireles, cujos poemas são ora objeto de análise, ao Catolicismo e, aos valores cristãos, por extensão. 
ou seja, do mito conforme criado e visto pelo homem —, fator capital para que tais narrativas não apenas vicejem, mas para que sejam retomadas noutros quadrantes, reformuladas e reconstruídas; por exemplo, conforme se dá na lírica de Cecília Meireles, em que os mitos são e não são mais os mesmos.

Já pela impossibilidade de se verticalizar a discussão de objeto tão vasto, optou-se por, na introdução do comentário aos poemas que integram o corpus, oferecer subsídios mínimos para que se tenham indícios da feição dominante de cada uma das entidades. Para tal, recorre-se tanto a caracterizações de segunda mão, como a obras literárias que contemplem as personagens. No contexto grego, adverte Jean-Pierre Vernant, os mythoi (narrativas), «tanto mais familiares quanto foram escutados ao mesmo tempo que se aprendia a falar, contribuem para moldar o quadro mental em que os gregos são muito naturalmente levados a imaginar o divino, a situá-lo, a pensá-lo.» (VERNANT, 2006, p. 15.) Antes de desdizer a tradição oral, que não se podia fixar, o acervo escrito com ela se amalgama e acaba por deixar um legado à posteridade. Sobre a condição desse manancial, afirma Brandão (2000, p. 25):

\footnotetext{
Os mitos gregos só se conhecem através da forma escrita e das composições imóveis da arte figurada, o que, aliás, é comum a quase todas as mitologias antigas. Ora, a forma escrita desfigura, por vezes, o mito de algumas de suas características básicas, como, por exemplo, de suas variantes, que se constituem no verdadeiro pulmão da mitologia. Com isso, o mito se enrijece e se fixa numa forma definitiva. De outro lado, a forma escrita o distancia do momento da narrativa, das circunstâncias e da maneira como aquela se converteria numa ação sagrada. Um mito escrito está para um mito «em função», como uma fotografia para uma pessoa viva.
}

Dentro desse entendimento, o espectro de investigação passará mais pelo diálogo entre textos e épocas do que, propriamente, entre a esfera ocupada pelo mito (fora do tempo e do espaço) e aquela figurada na poesia de Cecília Meireles (humana e, portanto, temporal). Na medida do possível, entrementes, indicam-se variações antigas dos mitos, de modo a mais bem se captarem as recuperações realizadas pela poetisa brasileira e os sentidos que acaba por, ela mesma, fixar dentro da reinscrição moderna e lírica do mito.

\subsection{Caronte}

Caronte (do grego Xópwv) é a divindade que transporta as almas sobre as águas do Rio Aqueronte («rio de dor») — «Um dos rios que as almas tinham de atravessar para chegar ao inferno» (KURY, 2001, p. 37), levando-as ao outro mundo, o Hades. O Rio Estige («rio odiado») 
e o Rio Cócito ( «rio das lamentações») são dois outros cuja travessia corresponde ao limite entre as duas esferas. No momento da passagem, cabia pagar a Caronte pelo traslado. O óbolo pago à divindade infernal consistia numa moeda, que era posta na boca dos corpos antes do sepultamento. Assim Robert Graves caracteriza a prática, que põe em contato dois mundos:

\begin{abstract}
Quando as almas descem ao Tártaro, cuja entrada principal se encontra num bosque de álamos negros ao lado do caudal do Oceano, os familiares piedosos colocam uma moeda debaixo da língua de seus respectivos cadáveres, para que elas possam pagar ao barqueiro Caronte, o avaro que as transporta em seu estranho barco através do rio Estige. (GRAVES, 2018, p. 192.)
\end{abstract}

Alvo de não poucas recuperações literárias e pictóricas na tradição ocidental, a personagem foi representada por Dante Alighieri, Michelangelo Buonarroti e Gustave Doré. Também se converteu em motivo da notável trilogia do dramaturgo português Gil Vicente, composta por Auto da Barca do Inferno (1517), Auto da Barca do Purgatório (1518) e Auto da Barca da Glória (1519). Nas peças, não há uma personagem nomeada a partir de sua contraparte helênica, mas há o Diabo, o "Arrais do Inferno», em situações que se aproximam daquelas respeitantes ao mitológico barqueiro da Antiguidade.

No plano clássico, entre menções e caracterizações efetivas, Francis A. Sullivan observa que Caronte já está presente na arte e na Literatura Grega dos séculos $6 .^{\circ}$ e $5 .^{\circ}$ a.C., bem como em monumentos etruscos do século $4 .^{\circ}$ a.C. em diante, quando é nomeado Charun e tem um aspecto animalesco. Há não poucos vasos e afrescos que trazem a sua imagem horrenda. E, embora nem Homero, nem Hesíodo citem a personagem, os dramaturgos Ésquilo e Eurípides a ela fazem referência. O mesmo sucede com Luciano de Samósata, no seu Diálogo dos Mortos. No plano latino, tanto Plauto como Juvenal recorreram à personagem dentro de um plano moral, empregando-a para «adornar uma história» ${ }^{6}$ (SULLIVAN, 1950, p. 11-13). HÁ poucas dúvidas de que, entrementes, é no Canto $6 .^{\circ}$ da Eneida que está configurada a representação mais detalhada de Caronte, o que, nas palavras de Sullivan (1950, p. 11), corresponde à «fixação de um tipo literário para o futuro». Em que pese a receber influxos dos que o antecederam para representar as «regiões não vistas», Vergílio, ao mesmo tempo em que conta aquilo de que «ouviu falar», oferece «sua própria interpretação» do que é o inferno (KEITH \& ABERNETHY, 1922, p. 345):

Hinc via Tartarei quae fert Acherontis ad undas.

\footnotetext{
${ }^{6}$ As citações de textos em língua estrangeira, salvo indicação contrária, consistem em tradução própria ao Português.
} 
turbidus hic caeno vastaque voragine gurges aestuat atque omnem Cocyto eructat harenam. portitor has horrendus aquas et flumina servat terribili squalore Charon, cui plurima mento canities inculta iacet, stant lumina flamma, sordidus ex umeris nodo dependet amictus. ipse ratem conto subigit velisque ministrat et ferruginea subvectat corpora cumba, iam senior, sed cruda deo viridisque senectus. huc omnis turba ad ripas effusa ruebat, matres atque viri defunctaque corpora vita magnanimum heroum, pueri innuptaeque puellae, impositique rogis iuvenes ante ora parentum: quam multa in silvis autumni frigore primo lapsa cadunt folia, aut ad terram gurgite ab alto quam multae glomerantur aves, ubi frigidus annus trans pontum fugat et terris immittit apricis. stabant orantes primi transmittere cursum tendebantque manus ripae ulterioris amore. navita sed tristis nunc hos nunc accipit illos, ast alios longe summotos arcet harena. ${ }^{7}$ (VERGILIUS MARO, 2019.)

A entrada de Enéas, acompanhado da Sibila, significa imergir na escuridão. Tudo nesse ambiente é funesto e muito das representações cristãs medievais do inferno corresponderá à imagem pintada com palavras por Vergílio (como se dá nas narrativas místicas, por exemplo). A sujidade demoníaca do barqueiro, assim, nada mais faz que emular a ambiência que habita. Mítica, a representação, assim, é fechada: todos os seus elementos convergem para uma unidade — neste caso, funesta e atemorizante. Conforme perceberam ainda Keith \& Abernethy (1922), conjuga-se à escuridão, à feiura e à putridez a magnitude das formas — da quantidade dos que habitam ao espaço ao tamanho propriamente dito deste.

De acordo com Kury, o herói Heraclés é dos poucos que, ainda vivos, conseguem ir ao inferno e retornar (KURY, 2001, p. 70). Heraclés o faz por meio da imposição de sua força, tomando o remo do barqueiro. Também Orfeu, em busca da amada Eurídice, vai e volta; para ir, mesmo que vivo, pelo toque mavioso de sua lira, que acaba por conquistar o barqueiro; para

\footnotetext{
${ }^{7}$ «Daqui começa o caminho que conduz às ondas do Aqueronte do Tártaro: é um golfo que borbulha, vasto abismo de lodo que referve e que vomita todo seu limo no Cócito. Um barqueiro horrendo guarda estas águas, e os rios, Caronte, de terrível sujidade, cuja barba abundante, branca e maltratada, Ihe cai do queixo; seus olhos cheios de chamas são fixos; pende-lhe das espáduas o sórdido manto amarrado com um nó. Por meio de uma vara impele a embarcação, dirige-a com a vela e transporta os corpos na barca cor de ferrugem; já a multidão ali espalhada corria para a margem, mães e homens e corpos de magnânimos heróis, privados da via, meninos e virgens e mancebos colocados nas fogueiras ante os olhos dos pais, tão numerosos como as folhas que giram e caem nos bosques ao primeiro frio do outono; tão numerosos como os pássaros que se agrupam, vindos do alto-mar para o continente, quando a fria estação os faz fugir através do oceano e os expulsa para as terras soalheiras. Agrupados, pediam que fossem os primeiros a passar, e estendiam as mãos na ânsia de atingir a outra margem. Mas o triste barqueiro acolhe ora estes, ora aqueles, e afasta para longe das margens aqueles que recusou.» (Trad. de Tassilo Orpheu Spalding.) (VERGílıO, 2001, p. 117-118.)
} 
voltar, também pelo dom da música, que seduz Perséfone, esposa de Hades, produzindo a concessão que faz o argonauta retornar ao mundo dos vivos; mas, por quebrar o acordo que fizera com as divindades, sem a amada (cf. CLARK, 2000, p. 193).

O poema "Caronte», presente na coleção Mar Absoluto, é composto por doze dísticos, que são como que os remos a conduzirem eu lírico e barqueiro. Essa estrutura alternada se justifica logo à partida da composição — e da jornada —, quando o eu poético, em vocativo, enuncia o nome da personagem grega: «Caronte, juntos agora remaremos: / eu com a música, tu com os remos.» (MEIRELES, 1985, p. 259.) Uma leitura calcada na tradição e nos visitantes que o ser infernal teve de conduzir ao Hades poderia levar à figura de Orfeu, cujo ofício está na música, contraposta aos remos de Caronte. Entrementes, depois de reconhecer que todos os seus antepassados embarcaram com a personagem mofina, o eu poético, na terceira estrofe, revelase mulher: «Mas eu sempre fui a mais marinheira: / trata-me como tua companheira.» ${ }^{8}$ A oração adversativa contrapõe esse eu feminino à sua própria ascendência e, longe de temer ou rechaçar a jornada ao lado da criatura demoníaca, assume uma postura convidativa, porque, diferentemente de pais e avós, parece dominada pelo espírito de curiosidade (como um artista...): quer desbravar.

O encantamento pelo desconhecido faz com que o eu lírico, antes de temer ou defrontar Caronte - pense-se nas figurações greco-latinas, conforme indicado —, queira ouvir-lhe, porque deseja conhecer, como a marinheira que vai a novas terras: «Fala-me das coisas que estão por aqui, / das águas, das névoas, dos peixes, de ti.» (MEIRELES, 1985, p. 259.) A música é para cantar e o desejo de saber está a ela atrelado; a passagem do plano físico ao imaterial «Meu corpo não viste: sou alma.» (MEIRELES, 1985, p. 259 - faz-se sem sofrimento, sem lamentação, com serenidade. Na sexta e na sétima estrofes, esse sentimento se patenteia: «Doce é deixar-se, e ternura o fim / do que se amava. Quem soube de mim? // Dize: a voz dos homens fala-nos ainda? / Não, que antes do meio sua voz é finda.» (MEIRELES, 1985, p. 259.) O mundo dos mortos, a nova experiência, embala a alma embarcada e para trás fica o que viveu em matéria. A ideia de jornada, demarcada desde os primeiros versos do poema, está ancorada num presente que serve de marco para o convite a Caronte («remaremos»); para a exposição das gerações passadas («Meus pais [...] / já também vieram»); para o imperativo ao barqueiro («Dize», «Rema»).

\footnotetext{
${ }^{8}$ Não é digna de descarte a noção de que o eu lírico assuma feição feminina pelo gênero daquilo que, no momento da trasladação, seja: uma alma. Entrementes, dadas as referências ao seu passado — ou seja, quando vivo o ente embarcado por Caronte — serem femininas («marinheira»), entende-se que a condição de mulher venha do outro lado, do lado dos seres viventes. É feminina não apenas por ser alma; é feminina por ser alma de mulher.
} 
Enquanto navega, o eu lírico de tudo quer saber sobre a nova condição e não se furta a seguir a prática, que lhe antecede, de pagar o barqueiro pela travessia; mas o faz em nova clave, se se considerar aquilo que tem a oferecer: «Pago-te em sonho, pago-te em cantiga, / pago-te em estrela, em amor de amiga.» (MEIRELES, 1985, p. 259.) Não mais com o óbolo que sob sua língua estivesse, mas com os dotes que parecem transitar do mundo dos vivos ao mundo dos mortos: o sonho, a cantiga, o amor... Em nada a atmosfera lembra terror ou desespero; não é uma recuperação conforme aquela que se vê, por exemplo, nas hostes infernais figuradas por Dante. O desejo de saber a tudo se sobrepõe, porque a alma marinheira é também uma alma lírica, motivada, assim, a inquirir o novo amigo, que não tem voz no poema — embora instado a falar - , mas que, pela repercussão do que expressa o eu poético, tampouco o rechaça: «Dize, a voz dos deuses onde principia, / neste mundo vosso, de perene dia? // Caronte, narra mais tarde, a quem vier, / como a sombra trouxeste aqui de uma mulher // tão só, que te fez teu amigo;» (MEIRELES, 1985, p. 259.) A vivenciar o momento de aprendizado, a alma/sombra também quer estar impressa na memória do ser mítico, num presente que se converterá em passado. Ou seja, mesmo no mundo dos deuses - pelo menos é este o entendimento humano — há um antes, um durante e um depois. Finda a passagem, o eu despede-se do companheiro de jornada, num sentido de serenidade que não rima com o perfil sedimentado no mundo clássico: «tão doce - ADEUS! — que canta até contigo!» (MEIRELES, 1985, p. 259.) Porque desejosa de saber, porque curiosa, porque afeita ao outro, porque poetisa, a alma transportada por Caronte transforma uma jornada miserável numa experiência gratificante.

\subsection{Diana}

A deusa Diana é, na Mitologia Latina, a correlata da deusa grega Ártemis — nas palavras de Graves (2018, p. 135), «anda armada de arco e flecha e [...] possui tanto o poder de rogar pragas ou morte súbita sobre os mortais quanto o de curá-los.» Ademais, é «a protetora das crianças pequenas e de todos os animais no período de lactância, mas também adora a caça, sobretudo a de cervos.» Em sua face latina, foi desde muito cedo adorada em templo romano a si dedicado, sobretudo por plebeus e escravos; as mulheres também a veneravam (cf. HARVEY, 1998, p. 162163). Arthur E. Gordon assinala que, já no século 6. ${ }^{\circ}$ a. C., segundo tradições literárias, o prédio do templo Aventino, em que a deusa era cultuada, encontrava-se erguido (GORDON, 1932, p. 178). Segundo o latinista, em decorrência também desse fator, torna-se possível acreditar que, apesar das aproximações que indiquem a filiação grega de Diana, as origens da deusa lacial estariam em Arícia; próximas, portanto, a Roma. Ainda segundo o estudioso, «A altura da 
helenização do culto de Diana e de sua identificação a Ártemis, que seria inevitável em face de consideráveis similaridades, [...] corresponde, aproximadamente, ao século 5. ${ }^{\circ}$ a. C.» (GORDON, 1932, p. 179.)

Por essa identificação, que se constituiu gradativamente, é natural encontrar em Catulo, poeta latino, no carme que dedica a Diana (o de n. 34) uma tipificação de atribuições que não deixa de repercutir na deusa latina marcas que são pronunciados no comportamento da deusa grega. $^{9}$

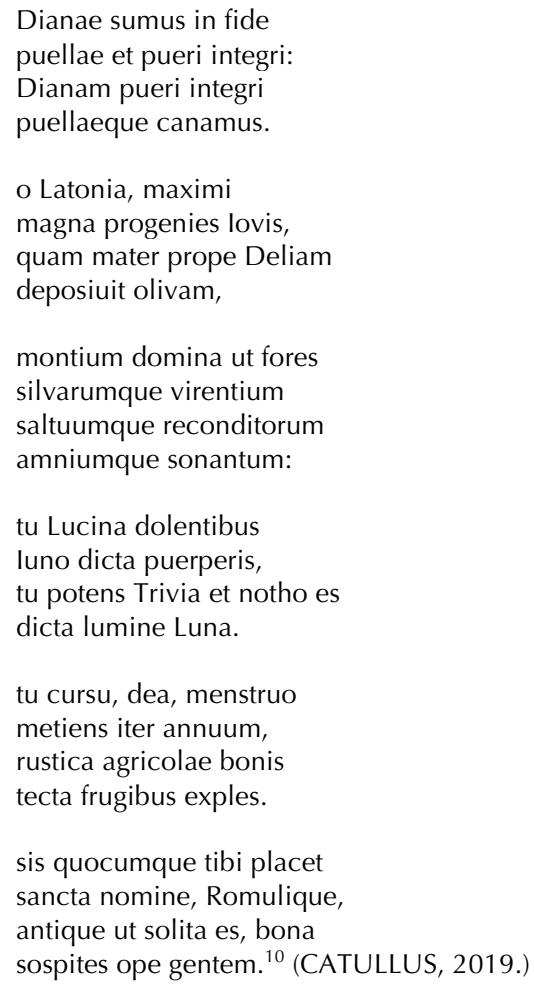

\footnotetext{
${ }^{9}$ No plano grego, em relação à deusa Ártemis, tem-se no trabalho mitógrafo Calímaco, a caracterização mais detalhada.

10 «Diana dá-nos proteção,

meninas puras e meninos,

Diana, puros, cantaremos,

meninos e meninas.

Ó Latônia, do imenso Júpiter progênie grande e generosa, que a mãe em Delos deu à luz ao lado da oliveira,
} 
A condição de deusa dos infantes se assinala na primeira estrofe do poema. A ascendência de Diana - filha de Júpiter, deus do dia, e de Latônia, deusa do anoitecer - expõe-se na segunda. Para além dos domínios por que circula (montanhas, florestas, rios etc.), duas outras esferas atinentes à Diana vêm à tona: nas encruzilhadas, ser invocada como Trívia; ser deusa das parturientes (Lucina, ou seja, que traz a luz). A ligação a Ártemis referenda, em Diana, a condição de uma deusa lunar e, simultaneamente, terrestre. Como sua equivalente grega, tem por epíteto «Senhora das Coisas Selvagens» (GRAVES, 2018, p. 139.) Sua ligação com a natureza e com a preservação da vida (também é deusa da fertilidade) parecem elementos salientes, em que pese a ser assinalado o seu uso do arco e da flecha, o que lhe confere a condição suprema de uma deusa guerreira, vinculada à caça e aos animais.

No livro Mar Absoluto, dois são os poemas que tratam da deusa romana: «Diana», dedicado ao poeta Manuel Bandeira; e «Obsessão de Diana», dedicado à cantora lírica e escritora Raquel Bastos. O primeiro texto traz a divindade como objeto, numa enunciação, toda ela, em terceira pessoa. Inicia com uma interjeição e a sequente caracterização dos afazeres de Diana, num plano em que o gerúndio assume uma dimensão mítica, do tempo que está além do tempo: «Ah, o tempo inteiro / perseguindo, de bosque em bosque, / rastros desfigurados!» (MEIRELES, 1985, p. 243.) O «tempo inteiro» acaba por se converter numa esfera em que, pela repetição, afirma-se uma verdade universal (ora, trata-se de um mito) e, por conseguinte, uma tarefa a que a deusa não se pode furtar. O presente do indicativo, empregado na segunda estrofe, é um reforço tanto à condição de Diana, quanto à inserção da deusa em sua ambiência. Falara-se dos «bosques» em que se buscam «rastros desfigurados»; agora, «As flores tocam-lhe / com blocos

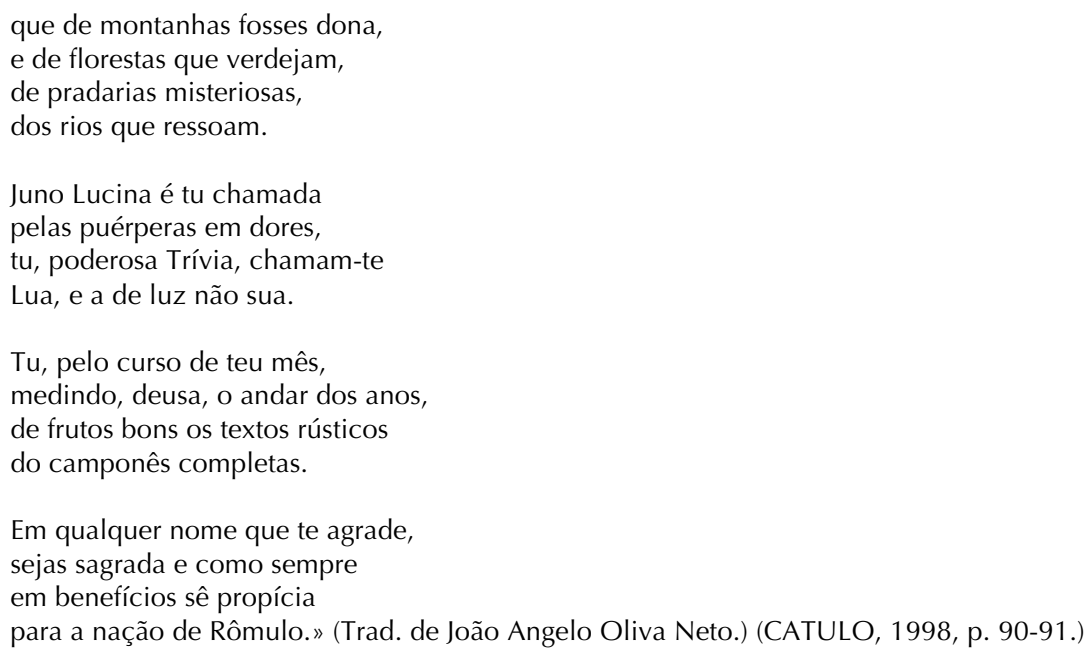


de aço a carne rápida. / E a chuva enche-lhe os olhos.» (MEIRELES, 1985, p. 243.) Exposta à natureza, a «carne rápida» da caçadora está ao alcance do toque das flores e da água das chuvas. Até aqui, trata-se de uma Diana análoga à de Catulo, para se ficar no exemplo dado.

As estrofes terceira e quarta correspondem a um trânsito temporal: do presente, vai-se a pretérito imperfeito. A implicação primeira da mudança parece evidente: sai-se do plano das verdades absolutas para o das ações usuais no passado. Sinaliza-se, assim, a mudança de um plano supratemporal a um outro, talvez mais humano, em que há falibilidade e a nota do hábito (mais humano que divino): «Manejava o arco / de tal maneira suave e exata / que era belo ser vítima. // Voltava à noite, / vazia a aljava, e pensativa, / com sua sombra, apenas.» (MEIRELES, 1985, p. 243-244.) Eis aqui uma Diana mais humana que divina: em que pese a sua destreza e a esvaziar, com precisão, a aljava das setas, retorna das caçadas só e a refletir.

Outra mudança temporal se registra nas estrofes finais do poema - a quinta e a sexta. $\mathrm{O}$ tempo verbal passa a ser o pretérito mais que perfeito, resultado de a caçadora ter retornado dos bosques e de se caracterizarem as ações que, no espaço natural, desenvolvera: «Nenhuma caça / valera a seta nem o gesto / da caçadora triste. // Nenhuma seta, / nenhum gesto valera o grito / reproduzido no eco.» (MEIRELES, 1985, p. 244.) Da mulher firme e certeira em suas flechadas, Diana, por pensar e restar solitária, deixa de fazer aquilo que lhe cabe: caçar. A naturalidade do ato, essencial à caçadora implacável, perde-se e, com isso, perde-se a essência da divindade, tornando-se, assim, falível. Do presente do indicativo, passando pelo pretérito imperfeito, até chegar-se ao pretérito mais que perfeito, o percurso da deusa latina como que a leva da divindade à humanidade. A dor do pensamento — essencialmente moderna — não poupa nem mesmo os deuses.

«Obsessão de Diana» é enunciado na segunda pessoa do singular; nele, assim, de objeto, a deusa se converte em destinatária das palavras do eu poético. A mesma noção de deslocamento, patenteada no poema anterior, está presente neste, com seu trânsito pelos elementos naturais, conforme visível nos versos iniciais: «Diana, teu passo esteve / em onda, em nuvem, na água / — e foi lúcido e leve.» (MEIRELES, 1985, p. 266.) O pretérito perfeito indica etapas cumpridas, num «passo» caracterizado por adjetivos aliterantes, que, por meio das consoantes líquidas, não apenas semântica, mas também foneticamente revelam os traços inerentes à deusa caçadora. $\mathrm{O}$ «passo» é também sujeito (agora, oculto) da segunda estrofe: «Tão rápido e tão belo / que era espanto senti-lo / e impossível prendê-lo.»(MEIRELES, 1985, p. 267.) Metonimicamente, a beleza e o caráter indômito de Diana se põem em evidência, com o destaque de sua agilidade em face de um eventual receptor. O eu poético, assim, parece tomar a própria experiência surpreenderia dar-se conta de algo assim — como condição geral no que diz respeito à 
percepção da deusa.

A perspectivação do eu lírico, expressa na parcialidade (tanto no sentido do que é tangenciado, quanto no do que é incompleto) com que a imagem de Diana é elaborada, referenda-se nas estrofes seguintes do poema, por procedimentos distintos: «Memória e sonho, agora, / - a existência visível / da veloz caçadora! // Bastaria querer-te / pelas estrelas nadas / de teu vestígio inerte.» (MEIRELES, 1985, p. 267.) Ágil, quase imperceptível aos olhos humanos, muito rapidamente a «existência visível» da deusa se converte em «memória e sonho»; em sua lonjura, o mito, para aquele que está no mundo sublunar, é mancha que mal se enxerga, mas se fixa no eu. Em Diana, tal situação se concretiza pelos seus dotes atléticos. A deusa, que passara «nuvem», «onda» e «água», deixa impressões de marcas pelas estrelas. O olhar, sentido que revela e que é portal da verdade humana, converte-se também no indicador — para o imaginário, enfim - do que se pode guardar daquela que habita uma região além, a das divindades.

Iniciada por uma conjunção adversativa, a última estrofe de «Obsessão de Diana» emprega tempo verbal ausente dos versos anteriores do poema: «Mas ah! quem descrevera / tuas mãos e teus olhos! / E teu rumo qual era!...» (MEIRELES, 1985, p. 267.) O pretérito mais que perfeito, que será suplementado pelo pretérito imperfeito, dá conta da impossibilidade humana de ter acesso à verdade/imagem da deusa Diana. Dela, nem as «mãos», nem os «olhos», tampouco o «rumo» se podem saber. Filtrada pela memória e pelo sonho do eu poético, a imagem que fica é, ela mesma, resultado de uma leitura lírica, porque ancorada mais na percepção de quem observa do que no alvo do olhar. A «Obsessão de Diana», assim, tanto pode corresponder à que diga respeito à deusa, de movimentar-se por todos os elementos em busca de sua caça; quanto do eu poético, que tenta a ver em efetivo, mas só alcança vestígios, a partir dos quais tece a sua caracterização.

\subsection{Narciso}

Uma das lendas que mais se revisitam, quando se pensa na Antiguidade Grega, é a de Narciso, o belo jovem que, encantado com a beleza da própria imagem refletida nas águas de uma fonte, acaba por encontrar a morte. As origens da personagem são caracterizadas em detalhes por Graves (2018, p. 430):

Narciso era téspio, filho da ninfa azul Liríope, que fora violada pelo deus fluvial Cefiso, após ter sido envolvida nos redemoinhos de suas correntes. $\mathrm{O}$ adivinho Tirésias disse a Liríope, a primeira pessoa que o consultou: «Narciso viverá até uma idade avançada, desde que jamais conheça a si 
mesmo.» Qualquer um poderia, com justa razão, ter-se enamorado de Narciso, mesmo quando ele era ainda uma criança. Aos 16 anos, seu caminho estava repleto de apaixonados de ambos os sexos, friamente rejeitados, tal era o obstinado orgulho que ele sentia da própria beleza.

Na caracterização da história conforme feita por Kury (2001, p. 276), há três versões possíveis: (1) as moças e as ninfas apaixonadas por Narciso, inconformadas pela indiferença do rapaz à sua corte e desejosas de vingança pela morte da ninfa Eco — vítima do amor por Narciso e incapaz de se comunicar com ele - , pedem vingança aos deuses, que fazem com que ele, cansado após uma caçada, debruce-se sobre as águas de uma fonte e feneça na imobilidade de contemplação da própria imagem; (2) um rapaz de nome Aminias apaixona-se por Narciso, que faz pouco caso do assédio e manda, ao jovem apaixonado, uma espada, com que esta acaba por se suicidar e, nos últimos suspiros, pede vingança aos deuses, a qual se consubstancia quando Narciso, deparando com a impossibilidade da paixão por si próprio, ao ver sua imagem refletida numa fonte, tira a própria vida; (3) Narciso é irmão gêmeo de uma jovem tão bela quanto ele; a moça vem a morrer e, ao ver a sua própria imagem refletida nas águas de uma fonte, tem lenificado o sofrimento pela perda, dada a semelhança entre ambos.

Ao se debruçar sobre a feição clássico-literária da lenda, Robert McMahon vai a Ovídio e a suas Metamorfoses e conclui que a profecia de Tirésias introduz três temas capitais: «O autoconhecimento, o orgulho e a problemática da penetração interpretativa.» (MCHAMON, 1985, p. 65.) A impossibilidade de o jovem chegar à maturidade como condicionada pelo não conhecimento de si próprio acaba por instaurar um jogo entre o interior e o exterior: a beleza externa e a sua valorização contrastam com a feiura interna, que viria à tona pelo conhecimento da primeira. Eis aí a condenação do jovem, porque traz em si forças opostas que não é capaz de conciliar.

Dentre as recuperações modernas feitas da lenda, uma das que mais bem retrabalham os pontos de vista é a do escritor inglês Oscar Wilde, no poema em prosa «O Discípulo». No texto, a piscina das águas doces que eram os prazeres de Narciso — pois que nelas se mirava converte-se numa piscina de lágrimas salgadas. Indagada sobre a tristeza gerada pela morte do jovem, «so beautiful was he» ${ }^{11}$, a piscina responde: «But I loved Narcissus because, as he lay on my banks and looked down at me, in the mirror of his eyes I saw ver my own beauty mirrored.» ${ }^{12}$ (WILDE, 1994, p. 246.) No seu «Epigrama, Cecília Meireles, menos operando uma inversão de papéis e mais modernizando o que vai no peito atormentado do belo jovem, Cecília Meireles

11 «tão belo ele era».

12 «Mas eu amava Narciso porque, quando ele se reclinava em minhas margens e abaixava o olhar, no espelho de seus olhos eu via a minha própria beleza refletida.» 
penetrará no íntimo da personagem para refletir sobre o que o atormenta.

O título do poema, «Epigrama», que está no livro Vaga Música, remete a um gênero que, em Grego Antigo, corresponde a «epígramma»; ou seja, «sobre o escrito» ou «sobre a inscrição» (MOISÉS, 1995, p. 190.) Massaud Moisés o define assim:

\begin{abstract}
Entre os gregos, primitivamente, o epigrama era tomado em sentido etimológico: designava toda sorte de inscrição, em túmulos [...], monumentos, estátuas, medalhas, moedas, etc., em verso ou prosa, votada à lembrança de um acontecimento memorável ou de uma vida exemplar. [...] Mais tarde, tornando-se breve e conciso, o epigrama cristalizou-se como fôrma literária, e ampliou o raio de seus temas, abrangendo o culto à liberdade, o ódio aos tiranos, o vinho e o amor, a sátira. (MOISÉS, 1995, p. 190.)
\end{abstract}

Diz, ainda, Moisés que a transição dessa forma poética para o plano latino correspondeu a uma sedimentação da brevidade associada ao pendor satírico. Não é bem essa a feição encontrada no texto de Cecília Meireles, que, assim, parece guardar mais expressivas semelhanças com o conceito helênico do gênero quando de suas origens: relaciona-se à exaltação de ente passado (como o epitáfio e a elegia), não tem cunho satírico e é breve/condensado (o que, de resto, parece comum à tradição do gênero em diversos quadrantes históricos).

«Epigrama» é enunciado na segunda pessoa do singular — ou seja, nele, Narciso é destinatário da fala do eu poético - e oscila entre o pretérito perfeito e o pretérito imperfeito, o que denota estarem concluídas as condições expostas e, eventualmente, o passamento do ente mítico a que se destinam as palavras. Aqui, portanto, confirma-se a articulação entre o gênero grego, na feição já indicada, e uma personagem igualmente grega - o recorte do título do poema, portanto, não soará fortuito e circunstancial; antes, ajusta-se com precisão ao tom adotado e ao objeto que contempla.

O poema de Cecília Meireles é dividido em três breves estrofes (duas com três versos e a última com três), e as duas primeiras são encabeçadas pelo vocativo que traz o nome de Narciso. Na primeira, lê-se «Narciso, foste caluniado pelos homens, / por teres deixado cair, uma tarde, na água incolor; / a desfeita grinalda vermelha do teu sorriso.» (MEIRELES, 1985, p. 180). O signo mofino da beleza que o jovem carrega - e por sua indiferença aos mais, resultado da condição que traz em si — reveste-o de uma dimensão trágica; combinação, aqui, de um destino e de seu cumprimento. As águas em que se mira são a superfície em que, numa primeira percepção, parece chocar-se com a constatação da própria graça, materializada num sorriso que é como uma «desfeita grinalda». O que é encantamento e satisfação, à partida, converte-se 
em motivo para choro; à partida, já se vê, porque o eu poético indica saber tudo aquilo que envolve a personagem, haja vista, insiste-se, os tempos verbais empregados. O destino não se vai cumprindo por etapas, antes, está traçado e consumado no momento da enunciação.

A colocação expressa do eu poético se faz na segunda estrofe, por meio do pronome pessoal. Apresentam-se, a esta altura, não apenas a detecção de ações da personagem e as suas consequências, mas também o que se passa em seu íntimo: «Narciso, eu sei que não sorrias para o teu vulto, dentro da onda: / sorrias para a onda, apenas que enlouquecera, e que sonhava / gerar no ritmo do seu corpo, ermo e indeciso,» (MEIRELES, 1985, p. 180.) Essa capacidade de olhar no interior de Narciso promove uma viragem no entendimento que se tenha do mito em sua feição primeva: o sorriso do belo jovem já não estará na constatação de sua beleza, mas naquilo que o integra às voltas da onda aquática. É como uma projeção que busca, na fixação em aguas que se agitam, um senso de eternidade que é vedado ao homem. Nisso, a segunda estrofe joga nova luz sobre a primeira (se se considerar que a leitura desta é guiada pela tradição): passa-se a saber que não é exatamente para a própria beleza que Narciso sorri amargamente, mas, sim, para a onda em que seu vulto se reflete.

A última estrofe do poema - mais breve que as duas primeiras e cujo sentido está plenamente articulado à segunda — tem, no primeiro verso, a continuação da estrutura sintática do que o antecede: «a estátua de cristal que, sobre a tarde, a contemplava, / florindo para sempre, com o seu efêmero sorriso...» (MEIRELES, 1985, p. 180.) A sede de eternidade do belo reside num senso de doação: a água que ondeia na fonte, coroada pelo «efêmero sorriso», já animada pelo vulto e pelo olhar de Narciso, consiste numa associação fugaz; o «para sempre» nada mais é que o desejo da personagem que parece entender a eternidade das coisas. Não por acaso, a imagem da «estátua de cristal», anelada por Narciso, acaba por se constituir num dos polos da máxima de Hipócrates, retomada por Sêneca: «Inde illa maximi medicorum exclamatio est: 'uitam breuem esse, longam artem'». ${ }^{13}$ (SENECA, 2019.) É um Narciso que vê, em analogia a uma elaboração humana - a estátua - a possibilidade de perdurar ao longo das épocas, já que os homens, eles mesmo, fenecem. O desejo daquele que vê as águas ondearem a anelada fixação em cristal não pode senão constrastar (do que é indício o sorriso de angústia) com uma realidade que se esvai: como a beleza, como as águas.

\footnotetext{
13 «Por isso, aquela expressão do pai da medicina: 'A vida é breve, a arte, longa'.» (Trad. de Lúcia Sá Rebelo, Ellen Itanajara Neves Vranas e Gabriel Nocchi Macedo.) (SÊNECA, 2006, p. 25.)
} 


\section{Epílogo}

Longe de esgotarem o potencial interpretativo dos quatro poemas, as leituras realizadas demonstraram alguns sentidos em que a recuperação, feita por Cecília Meireles, das personagens míticas greco-latinas, ao mesmo tempo em que cobra um conhecimento prévio dos entes figurados, enriquece-os, o mesmo sucedendo com a tradição. Ademais, a partir de ínfima ilustração, torna-se possível ver empreendidos alguns dos principais procedimentos poéticos da autora, tais como os jogos comparativos, a dilação entre o olhar e a realidade e, sobretudo, o filtro do imaginário, capaz de suplementar o que os sentidos captam do mundo à volta. Caronte, Diana e Narciso, ponto de partida das composições poéticas que se estudaram, não tomam banho no mesmo rio quando se banham nas águas da poesia moderna.

\section{Referências}

AUERBACH, E. Vico e o Historicismo Estético. In: Ensaios de Literatura Ocidental: Filologia e Crítica. S. Paulo: Duas Cidades; 34, 2007. p. 341-356.

BEARD, M.; HENDERSON, J. Antiguidade Clássica: uma brevíssima introdução. Rio de Janeiro: Jorge Zahar, 1998.

BRANDÃO, J. de S. Mitologia Grega. 15. ed. Petrópolis: Vozes, 2000.v. 1.

CATULLUS, V. Carmen Dianae. Disponível em <https://www.thelatinlibrary.com/catullus.shtml>. Acesso em 12.1.2019.

CATULO. O Livro de Catulo. S. Paulo: Edusp, 1998.

CLARK, R. J. P. Oxy. 2078, Vat. gr. 2228, and Vergil's Charon. The Classical Quarterly: new series, Cambridge, v. 50, n. 1, p. 192-196, 2000.

DAMASCENO, D. Poesia do Sensível e do Imaginário. In: MEIRELES, C. Obra Poética. 3. ed. Rio de Janeiro: Nova Aguilar, 1985. p. 13-36.

ELIOT, T. S. Tradição e Talento Individual. In: Ensaios. S. Paulo: Art, 1989. p. 37-48.

GORDON, A. E. On the Origin of Diana. Transactions and Proceedings of the American Philological Association, Baltimore, v. 63, p. 177-192, 1932.

GRAVES, R. Os Mitos Gregos. 2. ed. Rio de Janeiro: Nova Fronteira, 2018. v. 1.

HARVEY, P. Dicionário Oxford de Literatura Clássica Grega e Latina. Rio de Janeiro: Jorge Zahar, 1998.

JOLLES, A. Formas Simples. S. Paulo: Cultrix, 1976.

KEATS, J. Selected Poems. 3. ed. London: Penguin, 1996.

. Ode a uma Urna Grega. In: MARQUES, O. (Comp.). O Livro de Outro da Poesia de Língua Inglesa: em Inglês e Português. Rio de Janeiro: Ediouro, [19__], p. 42-45.

KEITH, A. L.; ABERNETHY, J. W. Vergil's Description of Hades. The Sewanee Review, Baltimore, v. 30, n. 
3, p. 345-351, Jul. 1922.

KURY, A. da G. Dicionário de Mitologia Grega e Romana. 6. ed. Rio de Janeiro: Jorge Zahar, 2001.

MCHAMON, R. The Christian Scripture of Ovid's Narcissus in the «Commedia». Pacific Coast Philology, Old Main, v. 20, n. 1-2, p. 65-69, Nov., 1985.

MEIRELES, C. Obra Poética. 3. ed. Rio de Janeiro: Nova Aguilar, 1985.

MOISÉS, M. Dicionário de Termos Literários. 7. ed. S. Paulo: Cultrix, 1995. PEÑUELA CAÑIZAL, E. A Poesia de Cecília Meireles. Revista de Letras, Araraquara, v. 8-9 p. 58-77, 1966. RAMOS, P. E. da S. Cecília Meireles. In: PAES, J. P.; MOISÉS, M. (Orgs.). Pequeno Dicionário de Literatura Brasileira: biográfico, crítico e bibliográfico. S. Paulo: Cultrix, 1967. p. 153.

PRADO, J. B. T. Inter-Relações e Permanência da Poética Clássica. In: VIEIRA, B. V. G.; THAMOS, M. (Orgs.). Permanência Clássica: visões contemporâneas da Antiguidade Greco-Romana. S. Paulo: Escrituras, 2011. p. 51-69.

SENECA, L. A. De Brevitate Vitæ. Disponível em: <https://www.thelatinlibrary.com/sen/sen.brevita.shtml>. Acesso em 2.1.2019.

SÊNECA. Sobre a Brevidade da Vida. Porto Alegre: L\&PM, 2006.

SULLIVAN, F. A. Charon, the Ferryman of the Dead. The Classical Journal, Chicago, v. 46, n. 1, p. 11-17, Oct. 1950

VERGÍlIO. Eneida. 7. ed. S. Paulo: Cultrix, 2001.

VERGILIUS MARO, P. Aneid VI. Disponível em <https://www.thelatinlibrary.com/vergil/aen6.shtml>. Acesso em 12.1.2019.

VERNANT, J.-P. Mito e Religião na Grécia Antiga. S. Paulo: Martins Fontes, 2006.

WILDE, O. Complete Short Fiction. London: Penguin, 1994.

Recebido em 03/03/2019.

Aprovado em 17/05/2019. 